\title{
ENTREVISTA COM O DRAMATURGO PORTUGUÊS FERNANDO GOMES
}

Maura Böttcher Curvello (FFLCH - USP) ${ }^{1}$

Entrevista realizada por Maura Böttcher Curvello, doutora pelo Programa de Pós-graduação em Literatura Portuguesa da FFLCH/USP, com o dramaturgo português Fernando Gomes. Algumas informações constam de sua tese de doutoramento: $O$ riso em movimento: da ironia de Camilo ao humor de Fernando Gomes. Os dados da primeira parte, com informações bibliográficas, foram colhidos durante a entrevista.

\section{INFORMAÇÕES BIOBIBLIOGRÁFICAS}

\section{Autor:}

\section{Nascimento (data, local, filiação)}

FERNANDO Alberto de Oliveira GOMES, filho de Alberto José Gomes e de Corina Fernanda da Conceição Oliveira.

Nasce a 22 de Janeiro de 1944, na cidade do Porto, freguesia do Bonfim.

\section{Formação/Atividade}

Curso Comercial na Escola Oliveira Martins, que não chega a completar.

Começa a trabalhar aos 16 anos (Empregado de escritório)

Muito tardiamente inscreve-se na Academia de Bailado Clássico de Pirmin Trecu, que se vê obrigado a abandonar para cumprir o serviço militar (1966).

Em 1967 parte para a Guiné, como Furriel Miliciano. Regressa ao Porto em 1969.

É convidado pelo Círculo Portuense de Ópera a participar na ópera de Pergolesi "La Serva Padrona" no papel de Vespone (personagem mudo), que estreia no Teatro S.João do Porto, em 1970.

Viaja por Espanha, França, Alemanha e Inglaterra, onde fica a trabalhar durante alguns meses.

Regressa a Portugal e fixa-se em Lisboa, onde trabalha como escriturário.

Pretende inscrever-se no Conservatório de Teatro, mas tal não é possível porque os horários não lhe permitiam continuar a trabalhar.

\footnotetext{
${ }^{1}$ Doutora em Literatura Portuguesa pela FFLCH/USP
} 
Em 1974 - e já com trinta anos - tem conhecimento de que Carlos Avilez, encenador e director do Teatro Experimental de Cascais, procura actores que não necessitam ter grande experiência, para dois pequenos papeis na peça de Claude Prin "Cerimonial para um Combate"; assim passa a integrar o elenco duma companhia de teatro profissional, uma das mais importantes do país, onde se mantém ao longo de três épocas.

Consciente dos seus poucos conhecimentos no que diz respeito à arte de representar, o TEC significou uma escola onde aprendeu os primeiros passos e Carlos Avilez o primeiro professor. Esta aprendizagem continuou com outros grandes encenadores como Filipe Lá Féria, João Brites e João Mota, com quem trabalhou nos anos seguintes. Em paralelo, começa a escrever textos de Café-Teatro, que representa em bares e pequenas salas; o êxito desta iniciativa encoraja-o para outros vôos e escreve a adaptação para teatro de “Alves \& Cia”, uma novela de Eça de Queirós (1986), “Drácula Júnior", um original inspirado em Drácula (1987) e uma versão teatral de “Maria! Não Me Mates que sou tua Mãe!”, de Camilo Castelo Branco (1988).

Ainda não parou de escrever, encenar e representar. A aprendizagem continua.

A impossibilidade de ter entrado para o Conservatório impediu-o de um maior conhecimento sobre a "História do Teatro" e o estudo de grandes autores. Todo o seu conhecimento foi adquirido nos palcos, com a prática.

Em 2002, juntamente com outros actores, forma a "KlássiKus" (Associação Cultural).

Em 2004 é convidado pela Escola Superior de Teatro e Cinema a trabalhar com os alunos do último ano do curso de Teatro; encena "Mestre Ubu".

\section{Obra (título, local, editora, ano de publicação. No caso de peça encenada: data, local, Cia. Teatral)}

Das dezenas de peças que escrevi nenhuma foi publicada. A intenção foi sempre e apenas a de escrever para serem encenadas e representadas. 


\section{ACERCA DE SUAS OBRAS}

\section{Qual (quais) julga ser(em) a(s) força(s)-motriz(es) de sua obra?}

O facto de escrever apenas sobre temas que conheço e usar uma linguagem simples.

Grande parte do que tenho escrito tem a ver com a realidade dos portugueses e o tema gira sempre à volta dos "sentimentos" desencadeados pela situação em que se encontram.

O amor, as grandes paixões, a saudade e o fado (o de ser português) são temas recorrentes e que me são familiares, tanto pela experiência de vida como pela memória. Além disso são universais.

Não querer ultrapassar as minhas capacidades para provar seja o que for e seja a quem for.

Ao escrever, ao encenar e ao representar, o que me motiva é o prazer de estar com os outros, contar-lhes histórias, partilhar com eles os tais sentimentos; e isso só é possível se for sincero. Foi também o caminho que eu encontrei para estar na vida sem me sentir só.

\section{Como se dá seu processo de criação?}

No caso de se tratar de uma adaptação, o primeiro passo é ler tudo o que estiver ao meu alcance sobre o autor e o seu tempo.

Em função dos actores que vão representar a peça, escolher as personagens que eles podem interpretar e que vão contar a história; no caso de Camilo Castelo Branco (são infindáveis as personagens nos seus romances, bem como o enredo) é evidente que têm de ser feitos grandes cortes, com o cuidado de manter o principal da obra.

Uma vez que escrevo a peça para de imediato ser levada à cena e conheço as dificuldades que vou ter de enfrentar (um número reduzido de actores, que irão ter de vestir diferentes personagens e um orçamento baixo para a montagem do espectáculo), obrigo-me a imaginar um cenário simples, que possibilite a criação de vários espaços; sabendo de antemão quem vai representar cada personagem, construir as cenas de forma a possibilitar o desdobramento. 
O mais importante é conhecer bem as personagens, saber o que pensam, como falam e o que as leva a actuar desta ou daquela maneira; depois, ao longo do trabalho de escrita, entrar na pele de cada uma e simplesmente "deixá-las" falar e passar para o papel aquilo que lhes vai na alma. Isto só é possível se as conhecermos bem; a elas e ao mundo que as rodeia.

No romance, o autor já fez isso e melhor que ninguém, apenas não o escreveu para ser apresentado num palco! Há que construir uma sequência de cenas que cativem o espectador desde a primeira e interessando-o sempre para a que segue, dosear o ritmo, surpreendê-lo pela forma como determinada cena é apresentada ou pelo desenvolver do próprio texto; transmitir-lhe a história duma forma interessante, imaginativa e viva.

Partilhar este conhecimento com os actores... e ensaiar. Dar-lhes liberdade para eles próprios recriarem as personagens e ter capacidade para alterar uma ideia préconcebida em função disso: um encenador não pode apenas limitar-se a dar indicações, tem de saber receber e aceitar sugestões. A construção dum espectáculo não é nunca (ou não pode ser) exclusividade do encenador. Todos os outros intervenientes, principalmente os actores, têm de sentir a importância da sua participação.

\section{Considera o subsídio governamental e/ou privado indispensável para o florescimento do teatro?}

Absolutamente. 